ISSN: 2162-3104 Print/ ISSN: 2166-3750 Online

Volume 8, Issue 3 (2018), pp. 1459-1478

(C) Journal of International Students

http://jistudents.org/

doi: 10.5281/zenodo.1254611

\title{
International Education is Political! Exploring the Politics of International Student Mobilities
}

\author{
Johanna L. Waters \\ University of Oxford, $U K$
}

\begin{abstract}
This article argues that, to date, debates (both public and academic) around international students and the internationalization of higher education have been overly concerned with economic issues and insufficiently attentive to the political ramifications of associated changes in educational practices. It takes seriously a call made by Madge et al. (2009), in which they assert that notions of "engaged pedagogy" and "responsibility" need to be explored in relation to international student experiences. Debates have thus far neglected the wider "politics" (with a small " $p$ ") that underpin the relationship between international students and their "host" university. An awareness of these political relationships has the potential to encourage progressive practices within the institution of the university, including the campus. The article examines the case of transnational education programs in Hong Kong, and considers why a political perspective on international student mobilities is important. The wider goal of this article is to inject some much needed "politics" into discussions of international-and domestic-student experiences.
\end{abstract}

Keywords: international students, politics, transnational education programs, Hong Kong

Ideas about mobility consistently risk becoming locked into ahistorical and depoliticized tropes that presume flattened geographies, opportunities without borders, and autonomous, raceless/genderless mobile subjects. (Stein and Andreotti, 2017, p. 135) 
This paper underwent revisions in the aftermath of an initial round of strike action by UK-based academics and other members of the University and Colleges Union. As reported by Xinhua (2018), the Chinese Embassy in Britain expressed "concerns" about the impact that the strike action was having on the thousands of Chinese nationals studying at UK universities. They are said to have voiced their concern to the Ministry of Education and promised to monitor the situation to ensure that the "legitimate rights" of Chinese students studying in the UK are being upheld. The involvement of the Chinese Embassy in this way has been one of many unexpected turns of events arising from this recent (and unresolved at the time of writing) industrial action. It neatly highlights the geopolitical and geostrategic importance of international student mobility in the wider context of the internationalization of higher education and the neoliberalization of the university (Smyth, 2017).

Prior to the strike action, international higher education in the UK was also receiving public interest and attention in relation to an ongoing political row over international student numbers and their inclusion within overall UK immigration statistics (see Waters, 2017 in The Conversation). As OECD (2017) figures attest, the UK hosts large numbers of international students on its university campuses (ranked second behind only the US, globally, as a destination country for international students). Some recent work by the Higher Education Academy (HEA) and HEPI (2017) (using responses to the National Student Satisfaction Survey) has shown that, compared to "home" students, international students in the UK demonstrate far lower levels of "satisfaction" with their experience.

The fact that the UK delivers higher education to an even larger number of students overseas (than it does to international students relocating temporarily to the UK), through transnational education (TNE), has not received anywhere near the same level of media (or academic) interest. According to the British Council (2018), TNE can be defined as "the provision of education for students based in a country other than the one in which the awarding institution is located. TNE essentially involves the mobility of providers or institutions and academic programs across jurisdictional borders to offer education...opportunities" (n.p.). TNE is a significant growth area in the UK's export strategy; the government has committed to increasing education exports from $£ 18$ billion in 2012 to $£ 30$ billion by 2020 (HE Global, 2016). Yet TNE raises so many unanswered and critical questions about: the ramifications of delivering higher education in different (non-UK) national contexts, the interaction between TNE and local/domestic higher education provision, the "reception" of TNE qualifications by local/domestic labor markets, the degree of knowledge that 
higher education institutions possess of the students they teach through TNE, and the spatialities attendant with these processes and interactions. This article focuses on the "university" as potential site, or place, of political possibilities for the manifestation of some of these issues. To date, TNE has invariably been discussed solely within a neoliberal (materialized, privatized, and commercial) frame of reference, which does the studentsboth domestic and international-a disservice.

The article begins by providing an overview of some of the key issues relating to the politics of international higher education followed by a discussion of academic literature on international student mobility (for higher education). Next, I consider how we might draw out some of the important political aspects of international student mobilities, including its postcolonial and decolonial dimensions. The final part of the article utilizes data collected during a project on transnational education and suggests some of the ways in which this area of internationalization might be both in urgent need of political intervention while also holding the potential to redress some of the most trenchant critiques of international higher education (Sayed et al., 2017; Stein, 2016).

\section{KEY ISSUES: AN OVERVIEW}

The internationalization of higher education has implications for how we understand international relationships and global responsibilities, not to mention local relationships and responsibilities (Stein, 2016). As Tannock (2013) argues, academics and policy makers need to pay far greater attention to the links between international and domestic students, particularly when it comes to issues around educational equity. He maintains that "demanding educational equality across borders, at the global level, could play a vital role in protecting the interests not just of international students, but domestic students as well" (p. 450). Whilst the economic arguments pertaining to international students in the UK are well rehearsed and commonly understood (they can pay up to three times the tuition fees of domestic students for the same course-Tannock, 2013), the non-pecuniary justification that UK HEI representatives have provided for the growth in TNE is less well known. It is claimed that TNE has the potential to forge progressive and equal international alliances that can:

rebalance [the] global higher education market, allowing more students to study in their own countries and reducing the costs to developing countries in terms of foreign exchange and "brain drain." It can build capacity both at home and overseas, a key driver for universities offering TNE and partners and countries 
hosting TNE alike. (HE Global-British Council and Universities UK, 2016, p. 9)

One interpretation of this quote might be, therefore, that TNE has the potential to foster a non-colonial form of overseas "development." And yet, this claim is built on almost no information on the actual nature of TNE "partnerships" other than a few small "case-study" examples. This claim is largely speculative and unsubstantiated. An alternative reading of the emphasis that the UK government is placing on TNE growth might be that by "offshoring" its international education (exporting education to students overseas), UK institutions are able to reap the financial benefits of international education (through tuition fees) without impacting immigration statistics. Later in this article, I will explore the latent promise of TNE to foster more egalitarian, decolonizing forms of learning.

There are two major, enduring lacunae in knowledge around international higher education - one that relates to public understanding and one that refers to academic debates. In the UK, public understanding of international higher education is limited to interventions around immigration control and, occasionally, to the funding of UK domestic higher education (although international education is notably absent from recent government documents on domestic HE policy, as noted by Brooks (2017); also, see Lomer, 2014). There has been no discernible discussion of the ethical dimensions of international higher education (see Stein, 2016) within the media or in UK policy. In particular, there has been little debate around the implications of "offshoring" higher education through TNE - whether this is in fact desirable - and how it relates to the international mobility of students (that come to the UK to study). There would seem to be inherent and yet largely unexplored problems linked to presenting "the internationalization of UKHE as a 'neutral experience' within normalizing conceptions of internationalization," instead moving towards achieving "a more 'layered" understanding that highlights the connections between the geographical, historical, political, economic and cultural spheres in order for an 'engaged pedagogy' to emerge" (Madge et al., 2009, p. 35). Unanswered questions remain about what it means to undertake international education responsibly and ethically, with a geographical sensibility; or to view students not as individualized, atomized, neoliberal consumers, but as inextricably embedded in wider social and spatial relations that will have global "ripple effects." Doreen Massey's (2004) work on "geographies of responsibility" is of great relevance for understanding the spatial (moral and relational) implications of international higher education. I concur with Clare Madge and colleagues, who have suggested that international education has the potential to be politically progressive. They have written that the "multi- 
sited, multi-scalar character of international study challenges simplistic dichotomies of here/there and unsettles the spatial imagination away from thinking about 'the international' and about pedagogy solely in relation to (largely unmarked) European-American-Australian centres, and instead explicitly locates itself as coming out of, and to, multiple locations" (Madge et al., 2014, p. 692). It is these multiple locations - the fact that through internationalization the university finds itself "multiply located"-that require institutions to adopt a global understanding of responsibility (towards their "overseas" students).

Some scholars have recently, tentatively, explored the internationalization of higher education from a critical perspective that encompasses ethical considerations-including Clare Madge, Parvati Raghuram, and Pat Noxolo's $(2009 ; 2014)$ work on postcolonial responsibility and international students, and Ravinder Sidhu's (2006) research on neoliberalism and internationalization (also, see Stein, 2016). These papers signal three broad areas of scholarship around international education that demand further consideration. Work on, first, ethics, care, and responsibility (especially in relation to postcolonialism, de-colonialism, neocolonialism, and development); second, neoliberalism and the contemporary university (the extent to which universities perceive students as neoliberal subjects whilst prioritizing raising revenue through international higher education over other concerns (Brooks et al., 2015)); and third, diversity and the politics of difference within the university. In this article, I will consider the first two of these important areas.

There is a pressing need, within the academy and beyond, for a discussion on the politics of international student mobility and the potential for universities to become progressive sites undertaking "engaged pedagogy" (Madge et al., 2009). All too often, economic debates, driven by neoliberal agendas, dominate discussions of international student mobility (Lomer, 2014). More recently, arguments about the relevance of "soft power" in higher education policy vis-à-vis international students have been made (Lomer, 2017). Sorely lacking is an understanding of the sense of political and social responsibility that universities should have for "their" international students. Furthermore, the dehumanizing of the international student means that they are rarely seen as political or social actors in their own right, but rather are portrayed as relatively inert bodies. The adoption of a "PREVENT" strategy within UK HEIs suggests that international students may become politicized in more nefarious ways. In the next section of the article, I briefly introduce the literature on international student mobilities before suggesting some of the ways in which a specifically political approach to these issues might be usefully introduced. 


\section{"POLITICS" OF INTERNATIONAL STUDENT MOBILITIES}

There is, now, a substantial literature upon which to draw when discussing educational mobilities. A decade or so ago, this was not the case-but over the past 15 years, geographers and sociologists have found a growing interest in studying movement for education (see Brooks \& Waters, 2011 for an overview of this work). "Migration scholars" have come to view student mobility as an important sub-set of highly skilled migration (King \& RuizGelices, 2003; Findlay et al., 2012), or even a "type" of migration in its own right (Raghuram, 2013). In multiple ways, international students have become more visible: in political discourse, on university campuses and in towns up and down the UK, and in academic debate (Beech 2014, 2018; Tran, 2016).

Interestingly, however, work on international students has tended not to engage with work on "student politics." As Brooks (2017) notes in her discussion of the ways in which social science has until recently represented "student politics," students have been frequently characterized in popular media as politically apathetic and uninterested. In the last few years, however, it has been increasingly apparent that students have had key roles to play in global and national political movements-such as the Occupy movement (in Hong Kong and elsewhere), the pre-democracy "umbrella" protests in Hong Kong and young people's recent mobilization in the 2017 UK general election; a large turnout among young people has been attributed to the significant swing of votes towards the Labour party and away from the Conservatives (the Conservative party won the election but lost a number of seats and failed to secure a majority, after a "landslide" in their favor had been widely predicted). Brooks also comments on "the role of higher education institutions in the politicisation of students" (2017, p. 1). Here, it is perhaps important to distinguish between the "institution" (an amorphous locus of power) and the physical site(s) of the university, and how such spaces might be used for political effects (social areas, walkways, squares, lecture halls, seminar rooms, residential blocks, and so on). The physicality (or materiality) of educational spaces is clearly an important consideration (see Brooks \& Waters, 2018) in understanding student political movements. The nuances of young people's politicization in relation to education, specifically, are suggested in a report by Jeffrey (2012), who is in fact making a wider point about "youth agency" and its different manifestations. As he explains:

Youth agency can only be apprehended by understanding how children and youth navigate plural, intersecting structures of power, including, for example, neoliberal economic change, 
governmental disciplinary regimes, and global hierarchies of educational capital. (p. 246; also, see Findlay et al., 2012)

Below I will discuss some findings from a research project on UK transnational education and how this might demonstrate issues around both "global hierarchies of educational capital," and a more rudimentary concern with "spatial variations in the quality of education" (Jeffrey, 2012, p. 246).

There are different ways in which we might approach, and attempt to understand, the politics of international education and student mobilities. For example, we might link international students to discussions around immigration and its "securitization" (Mavroudi \& Warren, 2013; Warren \& Mavroudi, 2011). In particular, this has entailed the use of restrictive and biomedical measures imposed by nation states in the policing of their borders, which have included the monitoring of international student mobilities. The politics of mobility, however, can also be about the differential access that individuals and groups of individuals have to mobility, and the power that this bestows upon them (see Massey's 1991 notion of "differential mobilities"; Waters, 2006; Tran, 2016; Forsberg, 2017). The politics of student relationships can be evoked with reference to Doreen Massey's work on relational space and responsibility. Massey (2004) writes:

If space is a product of practices, trajectories, interrelations, if we make space through interactions at all levels, from the (socalled) local to the (so called) global, then those spatial identities such as places, regions, nations, and the local and the global, must be forged in this relational way too, as internally complex, essentially unboundable in any absolute sense, and inevitably historically changing. (p. 5)

If we begin to view space in such relational terms, then we must also, thereby, adopt a more globally-oriented sense of responsibility and careone that avoids "that territorial, locally centred, Russian doll geography of care and responsibility"; a view "crucially reinforced by the persistence of the refrain that posits local place as the seat of genuine meaning and global space as in consequence without meaning, as the abstract outside" (Massey, 2004, p. 7).

There are also geopolitical arguments to be made around international study, but I am more convinced by those that pertain to the "geosocial" as the most strategic lens through which to understand this. In a recent article, Ho (2017) makes a compelling case for considering linkages developed through international education in terms of the "geosocial." Ho's (2017) research has specifically examined African educational migration to 
China. It begins from the point that much work on China-Africa relations has focused on either "geo-politics" or "geo-economics." In addition to the linkages between Africa and China that are being developed through trade, significant linkages are being forged, she argues, at the household level, as families undertake "transnational education projects" involving the migration of young adults to Chinese cities to attend university. In her article, the "geo-social" is defined as an intertwining of transnational social reproduction and global trade and politics (the coming together of geopolitics, geo-economics, and social reproduction), consequently highlighting the "geopolitical significance of education and concomitant power geometries populating the transnational circulation of knowledge" (Ho, 2017 , p. 16). Other writers have explored the "soft power" implications of international education, especially in relation to China (e.g., Caruana and Montgomery, 2015).

There has been a suggestion that, post-Brexit, new educational alliances and linkages will emerge between the UK and countries outside the EU, which might signify a period in the opening up - rather than closing down - of global relations. After Ho, however, I would suggest that it might also be useful to consider what these relationships indicate at a level "below" that of the nation-state or even the institution. We need to understand more about what international education means operationalized at the household or individual level, rather than simply in terms of policy and institution-wide practices. This article turns now to address, specifically, postcolonial (theoretical) perspectives on international higher education and the mobility of students.

\section{POSTCOLONIAL POLITICS AND INTERNATIONAL STUDENT MOBILITY}

The links between international education and postcoloniality have only very recently been addressed within extant scholarship. Madge et al.'s (2009) article on "engaged pedagogy and responsibility" provides one of the key texts in this regard. It makes some very important and insightful points about how we should think about "international students" (also, see Madge et al., 2014; Noxolo et al., 2012; Raghuram, 2013; Stein, 2016), stressing the connections between students and institutions, places and spaces, rather than seeing international education as something that "happens to" a small group of students in an isolated (often campus) location. "Engaged pedagogy" can only emerge from an open and frank understanding of the historical and contemporaneous imbalances of power and the reality of different types of exploitation underpinning the learning process and associated 
institutionalized "accreditation." They are keen, like other postcolonial scholars, to emphasize that colonialism is not "over" but "lives on" through contemporary academic practices.

Other recent explorations of postcoloniality and decolonization in relation to international education include Sayed et al.'s (2017) work on attempts to decolonize university curricula in South Africa, wherein they describe decolonization as a process of "expanding imaginations" that involves "rethinking what counts as relevant and rigorous scholarship" (p. 61). Their arguments clearly have a lot of relevance for thinking about transnational education in the context of post-colonial sites (such as Hong Kong). A focus on the legacy of colonialism in the lives of students within another post-colonial location-Malaysia - is provided by Koh (2017) in her excellent, recent book. She notes that "British colonialism introduced and implemented fundamental structural changes to Malaya - especially in the realms of race, education, citizenship, and the nation-state-that continue to underwire Malaysian social life during the post-colonial period. More importantly, this has implications for mobile Malaysians' culture of migration" (p. 50). The book goes on to demonstrate a direct link between colonial structures and institutions and contemporary international student mobility from Malaysia. Less directly, Kenway et al.'s (2017) work on elite schools at different global sites shows the ongoing legacy of colonialism in determining where (in the world) global elites choose to pursue higher education.

Arguments around decoloniality/postcoloniality have been especially germane in Africa, as Ndlovu-Gatsheni (2015) discusses in an influential essay on "decoloniality" and "the future of Africa." He argues that decoloniality is:

a necessary liberatory language of the future for Africa. Decoloniality speaks to the deepening and widening decolonization movements in those spaces that experienced the slave trade, imperialism, colonialism, apartheid, neocolonialism, and underdevelopment. This is because the domains of culture, the psyche, mind, language, aesthetics, religion, and many others have remained colonized. (NdlovuGatsheni, 2015, p. 485)

These arguments are particularly germane for discussions of education, and specifically international education where, as Madge et al. (2009) note, there has been a notable "lack of literature specifically focusing on the complex relational ties involved in caring for and thinking responsibly about international students" (p. 35). Indeed, certainly in policy literatures but also 
in many academic texts, the meaning of "international" in discussions of international education are rarely if ever explored. The postcolonial analysis deployed by Madge et al. (2009) when thinking about international students is applied to international students in the $U K$, where in some ways the underlying power dynamics might be easier to render explicit (although, in no way easy). It is even more challenging to think about what a postcolonial or decolonial perspective might bring to discussions of international student mobilities when TNE is involved. Why? Because, as research carried out by myself and Maggi Leung on TNE in Hong Kong has indicated, UK HEIs have a particular relationship with TNE students that evokes distance and apartness. For various structural, institutional, and ideological reasons (including the rather simplistic "out of sight, out of mind"), they take little responsibility for their TNE students. Ethical frameworks or discussions of ethics around TNE would seem to be largely absent. I return to this now, as I seek to demonstrate why I think there is a vital need for a discussion around the "politics" of transnational higher education.

\section{THE (ABSENT) POLITICS OF TRANSNATIONAL EDUCATION: A MODEL OF DISENGAGEMENT?}

I want to draw, here, on a recent project (mentioned above) that I completed on UK transnational higher education in Hong Kong, with colleague Maggi Leung (Utrecht University) (funded by the ESRC and RGC). In a series of publications (Leung \& Waters 2013, 2017; Waters \& Leung 2012, 2013a, 2013b, 2017), we have explored the unexpected and unintended implications of undertaking TNE qualifications for local students in Hong Kong. These implications were especially acute for students studying so-called "top-up"1 (undergraduate) qualifications. In the last section of this article, I want to extract some of the more pressing issues that arose for us that are, I believe, symptomatic of the absence of a "politics" of TNE. Whilst space precludes me from illustrating all of these in detail, I will first provide an overview of these concerns before preceding selectively to illustrate them where possible. In short, these concerns are with: 1) what is being taught (and the problematic concept of "knowledge transfer"); 2) the lack of recognition afforded to both the degree and the students/graduates; and 3) the lack of "control"/"responsibility" associated with sub-contracting or franchising a degree program.

1 "Top up" refers to the fact that these programs require a student to have done an Associate Degree or Higher Diploma first, which they will then "top-up" to "degree level" over the next 1 to 2 years. 


\section{Neo-Colonial Models of Knowledge Transfer}

In terms of what is being taught, we were not overly concerned with the pedagogical content of degree programs. We were more interested, however, in the model of "transference" that relies heavily upon colonial notions of Western knowledge and superiority. Because of the way in which TNE degrees operate (they necessitate this form of "knowledge transfer" from one country to another), the need for a frank consideration of how these programs might be "decolonised," as discussed above, would seem to be pressing. In reality, of course, knowledge transfer is never perfect or unfettered (as we have discussed in Leung \& Waters 2013 and Waters \& Leung 2017). But the principle of unproblematic knowledge transfer requires interrogation. The vast majority of TNE programs are set up at the instigation of the UK university "provider" who will make contact with a "host" for the program overseas (in this case, in Hong Kong) and establish a working relationship and some kind of agreement about how the program, and responsibilities for the program, will be administrated. Also, importantly, a deal is struck about how the funding received through student fees is divided. Official ownership of the program remains with the UK university - in all cases they retain charge for moderating and examining students' work (usually using an appointed external examiner) and issuing degree certificates. Usually, they provide all the teaching materials and suggest the course structure.

As we will see below, admissions are usually delegated and courses use a high percentage of "local lecturers" to deliver the teaching. It is required by the Hong Kong government that the program must be "on the books" at the same time at the UK "parent" university, making it very unlikely that the course content will have been tailored to its local audience and will instead involve a high degree of transplanting of knowledge. We found no evidence, in our research, that institutions were engaging in any way with discussions around the decolonizing of curricula or the problems that might attach themselves to the importing of British/Western ideas. Some of our UK staff interviewees did, however, acknowledge that in some cases use of local "case studies" or "examples" to illustrate theories or concepts might be more appropriate.

\section{Absent Recognition}

Students on, and graduates of, TNE programs complained consistently of a lack of recognition-both in terms of their actual qualifications and a subtler but nevertheless real absence of "social" recognition (recognition was denied to them by friends and family, the "host" university, employers, and government). This lack of recognition was 
obviously problematic and this was most clearly manifest in the difficulties graduates faced obtaining graduate-level jobs in Hong Kong (especially in the civil service where a degree was a requirement). Overseas qualifications were not recognized as degree-level qualifications. When some graduates sought recognition for their qualifications by paying for an independent assessment by a Hong Kong accreditation body (Hong Kong Council for Accreditation of Academic and Vocational Qualifications), they were invariably told that their qualifications were "equivalent" to a higher diploma or Associate Degree.

I will take a few moments, now, to discuss the issue of engagement between domestic and international students on "campus," that relates directly to the problem of non-recognition. TNE qualifications in Hong Kong are taught in various ways and at different sites - most commonly in private facilities "attached" to the continuing education arms of domestic universities, or delivered out of vocational education institutes. Many of the students we interviewed for our project were ostensibly attending one of several domestic universities for their program, and yet they received markedly different treatment from the students on "local" degree courses (i.e., those that had managed to secure a place at a domestic institution-a challenging feat as only $18 \%$ of young people leaving school are able to do so). The following example, taken from Waters and Leung (2013b), describes the "on-campus" issues faced by TNE students studying for a British undergraduate degree in Hong Kong:

Several students discussed this sense of "separation" between "real" university students attending the local HEI and themselves and other individuals on TNE programmes. As Angel $^{2}$ indicates, the feeling of separation is reinforced by a physical segregation, as some TNE students attend lessons outside the main university campus, in an off-shoot building within Hong Kong's commercial district. Students' access to university facilities and resources is also, consequently, curtailed ("There is no library in Admiralty"). Even on the main university campus, however, TNE students do not have access to the same resources as local university students, as Peter Chan here notes:

Local students could borrow 10 books from the library, but we could only borrow 5 books. Local students could borrow for 20 days; we could only borrow for 10 days.... The resources they

\footnotetext{
${ }^{2}$ All names are pseudonyms.
} 
gave us were obviously less than the local degree students. (Peter Chan, UK graduate, Hong Kong)

TNE students also reported differential access to: computing facilities, sports facilities, student discount shops, and halls of residence. All of these restrictions served to separate off TNE students from domestic students, inhibiting the development of institutionalised social capital. (p. 163)

Other students that we interviewed, like Leonie, received the teaching for their "British" degree on the campus of the Hong Kong Institute of Vocational Education (IVE). Even in that situation, transnational degree students were made to feel "unwelcome" and "inferior," as the following extract from an interview transcript describes:

I think the program/course is not rubbish, we do learn things from it. I think the arrangements of it could be improved, as I said, the study environment, as now there is no sense of belonging to the campus. I felt a bit [like] I was not being respected. I did not use much of their resources. I would at least have a proper computer room in my higher diploma in IVE [previous qualification]. In my top-up degree, I had to share resources with the IVE students in that campus. The computer room was very small, only got two computers. I felt being ignored.

Interviewer: Do you go there often?

No, not often, because it is annoying, I ought to fill in forms, etc., to get in. So I felt they were just forcing us not to use the room. We just had a feeling that we did not want to stay in the campus longer. It made us feel that we wanted to leave the campus after class. I would not feel like staying in the campus to do my assignments nor revision. Unless it is necessary, or else I would not want to be there. (Leonie Cheung, age 23, was studying for a one-year British "top-up" degree).

Through our research we also found that for many students, the large teaching groups prevented important bonding between classmates:

They split us 110 plus students into two lecture classes, so one is about 50-60 in each lecture class. For tutorial classes there are 10-20 students...the bonding with those 10-20 friends is relatively strong, but the bonding amongst the 65 students is not strong. And now I only keep in touch with 3-4 friends from the 
program. I might not recognize the others if I see them on the street. (George Law, Hong-Kong based UK TNE graduate)

This lack of opportunity for "bonding" has a significant impact upon the type and quality of institutional social capital that students on TNE programs are able to develop. It meant that very few students built robust and meaningful social connections with classmates and alumni (Waters, 2007). Furthermore, TNE programs lacked any "student activities," leaving some individuals feeling that "we had a weak sense of belonging." In the following interview extract, these problems are highlighted:

I think this program was unable to give me a university life...As a student of the "top-up" program in X [Hong Kong] University, I was unable to enjoy the facilities in the university fully... I felt the good things of those local degree students...I could see that they had many functions in the concourse [of the university]-there were forums, singing contests, and many different activities. [Interviewer: Did you join those activities?] No, I could not have those benefits. Students of non-local programs were not recognized to be the students of X University [in Hong Kong]. Therefore I had a feeling of being isolated. (Chloe Lee, graduated with a UK TNE degree, Hong Kong)

As noted above, the host institution in Hong Kong also fails to recognize TNE students, leaving them with a sense that they are "not real students." One further aspect of TNE that prevents the possibility of any "integration" between home and "host" students is the spatial separation on an international scale - almost all of the programs that we looked at involved no international mobility on the part of the student. Consequently, the student found it impossible to feel part of their overseas host institution, just as the overseas host institution for the most part did not consider TNE students in the same terms as students resident in the UK.

\section{Institutional Disengagement}

Also significant, and largely unexplored within research on TNE, is the use of local, part-time, and precarious lecturers to deliver these programs. This is evident on both "franchised" programs (where the UK institution sells the whole degree to an overseas institution to deliver) and those that employ a "flying faculty" model (where the UK institution retains a degree of control over the program, including teaching some of the course). What was apparent from our research was that where flying faculty were used, they were generally used for a very small proportion of the 
overall contact hours. I asked one UK university to clarify who does the teaching on their degree programs in Hong Kong:

Local teachers. Originally, when the course started, there would have been probably full-time staff at XX [local Hong Kong university hosting the UK program], but because of changes there over the years, it's harder for their staff. These are now almost professional part-time lecturers. Often our lecturers [those that teach on the UK TNE program] also teach at Hong Kong University, Hong Kong Poly U, etc.

In other words, it is very common for universities in Hong Kong to contract out the teaching to part-time or agency staff, who will teach on more than one TNE program owned by more than one UK university. The reason he gave for this was also interesting: "[because] they're looking at students who aren't sort of full-time students....so they won't use their full-time staff on it." He went on to describe how one particular TNE course has in excess of 300 students on it (up from around 40 originally). Others, we were told, had more than 600. Large class sizes and student numbers also make the UK institution less likely to take full responsibility for students on their TNE programs.

Leonie, a student introduced above, expressed concerns about the lack of UK teaching staff on her UK degree program. We asked her what was "British" about her program:

I could not feel anything, absolutely nothing, except the certificate had printed the UK university. But...the lecturers were from XX [the Hong Kong institution at which the program was "based"]...I am not sure whether the lecturers, whether they taught IVE day school, for higher diploma...I think that throughout this top-up degree program, the professor would come to Hong Kong [from the UK], for only once, which I think that time is a bit meaningless.

Interviewer: How long do they come for "once"?

They come for one lecture, only one lecture. Maybe about three hours. Then that's it.

Just as UK universities have little (or no) control over who teaches on their courses in Hong Kong, similarly the admission processes are also delegated to the Hong Kong institution. I asked another UK university, "do you have any hand in the recruitment process?" and they replied: 
No, we delegate that. I am not sure whether this was the case from day one...I suspect that right from the outset we did scrutinize the applications. But over the years we've delegated the recruitment to colleagues in Hong Kong, to the point that we don't really look at the application forms of students [at all]. We don't really scrutinize applications any more.

What we see in all these examples is a clear sense of "separation" between the UK university that "owns" and awards the TNE qualification, the Hong Kong institution that houses the degree program, and the staff that teach on the program.

\section{CONCLUSIONS}

International students draw universities into global webs of responsibility, whether they like it or not (Massey, 2004). They increase their global reach and influence in more ways than are presently acknowledged. It is, therefore, unacceptable for institutions solely to view international students in pecuniary terms. They need to be seen as individuals, firstly, then as members of a global community. In the context of the UK, "Brexit" (the UK's imminent exit from the European Union) presents an opportunity to reassess how it sees its place in the world. Indeed, a great deal of soul searching has already been undertaken. Moving forward, institutions (and the UK as a whole) must be willing to confront: a sense of responsibility for (international) students; and a sense of responsibility for the spaces with which UK HEIs are intimately connected through internationalization. This inevitably involves coming to terms with the politics of international education.

In this article, some of the problems attendant with transnational educational programs have been highlighted. However, it might also be possible to see some liberating, decolonizing potential in TNE. Might TNE not offer the chance to develop a curriculum that explicitly "decentres the nation-state" (Stein and Andreotti, 2017, p. 138)? In its own way, might it not already be doing this, but in an unstated, underrated sense? Through the use of local untenured lecturers, for example: UK institutions have no real grasp on what, exactly, they are teaching, or how. We have evidence from students that they invariably teach in Cantonese (even though the course is "supposed" to be taught in English). This might be seen as a subtle "political" intervention of sorts (Cheng, 2016); a way of recapturing the program and making it more local. If UK universities were to engage more with their TNE student body, might that engagement not enrich the student body as a whole? In one (exceptional) interview with a UK university, this 
idea was even mooted. I asked how he (a UK lecturer in charge of a set of TNE programs) viewed these courses:

Basically, I see them as broadening the base of this university. Let's face it, a university at $X$ [city in Wales] is, by its nature, small. Unfortunately, most of the local students are extremely parochial, they won't go anywhere, won't do anything....Anything we can do either to bring foreign students here or to wake people up.... Wales is a small country and it needs to deal with the outside world, it does not need to be totally inward looking...If we can get outside contacts now...My mission in life is to keep all the international stuff going, keep the international contacts going. One day it will break through; one day it will happen.

He was the only staff member of a UK university interviewed (out of 18 institutions) to make any mention of the potential of TNE students to the diversity of the student body. It is a very interesting claim and stands out for its exceptional nature. It is suggestive, however, of a different way to view TNE; of a more progressive, less pecuniary perspective on the growth of these programs. Nearly all the UK universities we interviewed were open about the monetary importance of TNE for either subsidizing domestic programs or paying UK staff wages. Sadly, this emphasis on finances comes at the expense of an ethical and connected "world view" within which TNE programs and students become a part of domestic programs and student bodies. This might not simply be ethical but also fundamentally enriching and necessary.

\section{ACKNOWLEDGMENTS}

I would like to thank Maggi Leung for her work on the joint project referred to in this article, and Yutin $\mathrm{Ki}$ for his research assistance and the ESRC and RCG Hong Kong for their financial support (RES-000-22-3000). CindyAnn Rose-Redwood has been extremely patient with me - thank you. And two anonymous referees provided very helpful comments on the first (very rough!) draft of this article.

\section{REFERENCES}

Beech, S.E. (2014). Why place matters: Imaginative geography and international student mobility. Area, 46(2), 170-177.

Beech, S.E. (2018). Adapting to change in the higher education system: International student mobility as a migration industry. Journal of Ethnic and Migration Studies, 44(4), 610-625. 
British Council. (2018). Retrieved from: https://www.britishcouncil.org/ education/ihe/knowledge-centre/transnational-education.

Brooks, R. (2017). The construction of higher education students in English policy documents. British Journal of Sociology of Education, doi: $10.1080 / 01425692.2017 .1406339$

Brooks, R., Byford, K., \& Sela, K. (2015). The changing role of students' unions within contemporary higher education. Journal of Education Policy 30(2), 165-181.

Brooks, R., \& Waters, J. (2013). Student mobilities, migration and the internationalisation of higher education. Basingstoke: Palgrave Macmillan.

Brooks, R., \& Waters, J. (2017). Materialities and mobilities in education. London: Routledge.

Caruana, V., \& Montgomery, C. (2015). Understanding the transnational higher education landscape: Shifting positionality and the complexities of partnership. Learning and Teaching, 8(1), 5-29.

Cheng, Y.E. (2016). Learning in neoliberal times: Private degree students and the politics of value coding in Singapore. Environment and Planning A, 48(2), 292-308.

Findlay, A., King, R., Smith, F., Geddes, A., \& Sekldon, R. (2012). World class? An investigation of globalisation, difference and international student mobility. Transactions of the Institute of British Geographers, 37(1), $118-131$.

Forsberg, S. (2017). Educated to be global: Transnational horizons of middle class students in Kerala, India. Environment and Planning A, 49(9): 2099-2115.

HE Global-British Council and Universities UK, 2016 (p. 9).

HESA and HEPI (2017) 'Student academic experience survey' Retrieved from: http://www.hepi.ac.uk/wp-content/uploads/2017/06/2017-Student-AcademicExperience-Survey-Final-Report.pdf

Ho, E.L. (2017). The geo-social and global geographies of power: Urban aspirations of 'worlding' African students in China. Geopolitics, 22(1), 15-33.

Hopkins, P. (2011) Towards critical geographies of the university campus: Understanding the contested experiences of Muslim students. Transactions of the Institute of British Geographers, 36(1), 157-169.

King, R., \& Ruiz-Gelices, E. (2003). International student migration and the European "year abroad": Effects on European identity and subsequent migration behaviour. Population, Space and Place, 9(3), 229-252.

Jeffrey, C. (2012). Geographies of children and youth II: Global youth agency. Progress in Human Geography, 36(2), 245-253.

Kenway, J., Fahey, J., Epstein, D., Koh, A., McCarthy, C., \& Rizvi, F. (2017). Class choreographies: Elite schools and globalization. Cham: Springer.

Koh, S.Y. (2017). Race, education, and citizenship: Mobile Malaysians, British colonial legacies, and a culture of migration. Cham: Springer.

Leung, M., \& Waters, J. (2017). Educators sans frontières? Borders and power geometries in the transnational education social field. Journal of Ethnic and Migration Studies, 43(8), 1276-1291.

Leung, M., \& Waters, J. (2013). British degrees made in Hong Kong: An enquiry into the role of space and place in transnational education. Asia Pacific Education Review, 14(1), 43-53 
Lomer, S. (2014). Economic objects: How policy discourse in the United Kingdom represents international students. Policy Futures in Education, 12(2), 273-285.

Lomer, S. (2017). Soft power as a policy rationale for international education in the UK: A critical analysis. Higher Education, 74(4), 581-598.

Madge, C., Raghuram, P., \& Noxolo, P. (2009) Engaged pedagogy and responsibility: A postcolonial analysis of international students. Geoforum, 40(1), 34-45.

Madge, C., Raghuram, P., \& Noxolo, P. (2014). Conceptualizing international education: From international student to international study, Progress in Human Geography, 39(6), 681-701.

Marginson, S. (2012. Including the other: Regulation of the human rights of mobile students in a nation-bound world. Higher Education, 63(4), 497-512.

Massey, D. (1991). The political place of locality studies. Environment and Planning A, 23(2), 267-281.

Massey, D. (2004). Geographies of responsibility. Geografiska Annaler: Series B, Human Geography, 86(1), 5-18.

Mavroudi, E., \& Warren, A. (2013). Highly skilled migration and the negotiation of immigration policy: Non-EEA postgraduate students and academic staff at English universities. Geoforum 44, 261-270.

Ndlovu-Gatsheni, S.J. (2015). Decoloniality as the future of Africa. History Compass, 13(10), 485-496.

Noxolo, P., Raghuram, P., \& Madge, C. (2012). Unsettling responsibility: Postcolonial interventions. Transactions of the Institute of British Geographers, 37(3), 418429.

OECD (2017). Education at a glance. Paris: OECD Publications.

Ong, A. (1999). Flexible citizenship: The cultural logics of transnationality. Durham: Duke University Press.

Raghuram, P. (2013). Theorising the spaces of student migration. Population, Space and Place, 19(2), 138-154.

Robertson, S. (2011). Student switchers and the regulation of residency: The interface of the individual and Australia's immigration regime. Population, Space and Place, 17(1), 103-115.

Sidhu, R. (2006). Universities and globalization. To market, to market. New Jersey: Laurence Erlbaum Associates Ltd.

Sayed, Y., Motala, S., \& Hoffman, N. (2017). Decolonising initial teacher education in South African universities: More than an event. Journal of Education (University of KwaZulu-Natal), 68, 59-91.

Stein, S. (2016). Rethinking the ethics of internationalization: Five challenges for higher education. InterActions: UCLA Journal of Education and Information Studies, $12(2)$, n.p.

Tannock, S. (2013). When the demand for educational equality stops at the border: Wealthy students, international students and the restructuring of higher education in the UK. Journal of Education Policy, 28(4), 449-464.

Tran, L.T. (2016). Mobility as "becoming": A Bourdieuian analysis of the factors shaping international student mobility. British Journal of Sociology of Education, 37(8), 1268-1289.

Warren, A., \& Mavroudi, E. (2011). Managing surveillance? The impact of biometric residence permits on UK migrants. Journal of Ethnic and Migration Studies, 37(9), 1495-1511. 
Waters, J.L. (2006). Emergent geographies of international education and social exclusion. Antipode, 38(5), 1046-1068.

Waters, J.L. (2007). "Roundabout routes and sanctuary schools": The role of situated educational practices and habitus in the creation of transnational professionals. Global Networks, 7(4), 477-497.

Waters, J. (2017). Now we know most international students go home after their courses - The vilification must end. The Conversation August 24. Retrieved from: https://theconversation.com/now-we-know-most-international-studentsgo-home-after-their-courses-the-vilification-must-end-83008

Waters, J., \& Leung, M. (2017). Domesticating transnational education: Fortifying discourses of social value and self-worth in "meritocratic" Hong Kong. Transactions of the Institute of British Geographers, 42(2), 233-245.

Waters, J., \& Leung, M. (2014). "These are not the best students": Continuing education, transnationalisation and Hong Kong's young adult "educational non-elite." Children's Geographies, 12(1), 56-69.

Waters, J., \& Leung, M. (2013a). Immobile transnationalisms? Young people and their in situ experiences of "international" education in Hong Kong. Urban Studies, 50(3), 606-620.

Waters, J., \& Leung, M. (2013b). A colourful university life? Transnational higher education and the spatial dimensions of institutional social capital in Hong Kong. Population, Space and Place 19(2), 155-167.

Waters, J., \& Leung, M. (2012). Young people and the reproduction of disadvantage through transnational higher education in Hong Kong. Sociological Research On-line, 17(3), 1-6.

Xinhua (2018) http://www.xinhuanet.com/english/2018-03/01/c_137006815.htm

JOHANNA L. WATERS, PhD, is Associate Professor in Human Geography at the University of Oxford and a Fellow of Kellogg College. Her most recent book, with Rachel Brooks, entitled Materialities and Mobilities in Education, was published by Routledge. She is presently working on a number of projects around the internationalization of education and student (im)mobilities, including one on crossborder schooling and another on satellite campuses of UK universities. Email: johanna.waters@ouce.ox.ac.uk 